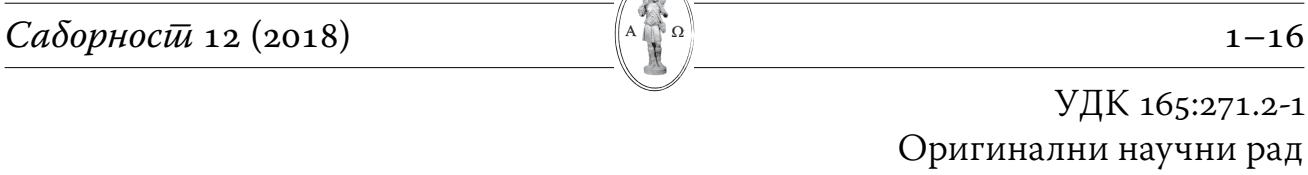

\title{
Игнатије Мидић"
}

Универзитет у Београду, Православни богословски факултет, Београд

\section{Основни елементи православне гносеологије}

\begin{abstract}
: Будући да је знање једино оно које се може искористити, односно које доноси моћ, онда је оно, као што показује и савремена цивилизација, врло опасно по онога који сазнаје. Чињеница је да наше савремено знање, преточено у моћ, преточено у технологију, угрожава не само нас као људе, него и читаву планету и читав систем живота. Зато је проблем (Бого)познања врло актуелан. Православни допринос гносеолошком питању огледа се у приступу, који познање сматра личносном, еклисиолошком и сотириолошком категоријом, о чему сведоче и предањски и светоотачки извори.
\end{abstract}

Key words: гносеологија, ум, знање, љубав, Црква, личност, Свети Максим Исповедник.

$\prod$ роблем знања, сазнања уопште, не само Бога, него уопште сазнања свега онога што нас окружује прастари је проблем. Савремени појмови о томе како сазнајемо себе и свет око себе, различити су у односу на то какви су они били у старој Грчкој и уопште у хришћанском свету, до VIIVIII века. Оно што је карактеристично за савремено знање је чињеница да се ради о знању ради искоришћавања, и то управо у смислу оног Беконовог става да је знаңе моћ. Односно, сазнати нешто не значи сазнати га ради њега самога, него зато да бисмо га могли искористити. Карактеристична појава у Западном свету јесте то да свако знање које се не може искористити, које не даје никакву материјалну корист, бива поистовећено са незнањем. Зато је све већа тежња на Западу да се, рецимо, затварају школе као што су философске, теолошке итд., јер је управо то тип знања које не може да се репродукује, не може да се искористи, као што рецимо може да се искористи знање прављења ципела, или зидање зграда, речју, знање које може да се уновчи. Одбацују се, наиме, она знања која немају комерцијалну димензију.

Нажалост, и у Цркви и уопште код људи који се баве сазнањем Бога, преовладао је тај однос према сазнању. Можда несвесно, али и ми данас све више захтевамо и од теологије да када говори о Богу говори тако да одмах

ignatije@bfspc.bg.ac.rs 
можемо да видимо које су конкретне користи од тога. То се манифестује на различите начине. Рецимо, данас је све више људи који, када се моле Богу, а не добију одговор на своју молитву, брзо закључе да Бог и не постоји! То показује да сама проблематика сазнања и уопште односа према Богу треба да буде сврсисходна да би постојала. Ако нема никаквих одговора на оно што се тражи, тада у ствари то и не постоји и не би требало тиме да се бавимо. Понекад тај однос према Богу, али не само према Богу него и према другим људима, личи на однос према машинама, од којих очекујете жељени производ у складу са уложеним новцем. Ако се то не деси, ако машина којим случајем не избаци очекивани производ, онда је она покварена и треба да се склони. Такав је данас нажалост однос и према другим људима, и према стварима које нас окружују, а и према Богу.

Будући да је знање једино оно које се може искористити, односно које доноси моћ, онда је оно, као што показује и савремена цивилизација, врло опасно по онога који сазнаје. Чињеница је да наше савремено знање, преточено у моћ, преточено у технологију, угрожава не само нас као људе, него и читаву планету и читав систем живота. Мислим да би од овог проблема требало почети онда када себе постављамо као субјект сазнања у односу на оно што се сазнаје. Ја сам у ранијим радовима ${ }^{\mathbf{1}}$ желео да покажем да мейоg сазнања итекако одређује објекй сазнања. Почео сам са сазнањем ствари. Ствари управо и јесу ствари, јесу мртве ствари, из односа који имамо према њима. Ако тај исти однос задржимо и према живим људима, и према Богу, и они ће за нас постати ствари. Рецимо, ако човеку прилазите као што прилазите стварима у процесу сазнања, ако његов идентитет одређујете на основу његове појавне форме, у смислу његове природе, његове висине, његовог порекла итд. тада човек неминовно постаје ствар, зато што се идентитет који му при томе дајете може наћи у хиљаду других ствари. Рецимо да је добар, услужан, користан, леп... То се све може рећи и за једну машину, за један ауто или нешто слично.

Постоји, међутим, другачији начин сазнања који је утолико драгоценији што у процесу познања, другога пројављује као личнос $\bar{u}$, као непоновљиву личност, али који и ствари, и природу око нас, ако им се приступа на тај начин, оживљава, онако како и треба да буде, јер је Бог иначе створио природу да она учествује, да партиципира у нашим људским односима, и да на тај начин и она оживи. У Цркви кажемо: да постане Тело Христово. А она може постати Тело Христово једино ако се уноси у зајеgницу, ако буде предмет љубави. Ту сазнање добија једну другу димензију него што је то код Бекона и данас, добија други идентитет. Није више знање као моћ, него знање као gруіи, као служење gруїме у којем и ми, као субјект који сазнаје, постајемо непоновљива личност.

1 Уп. Мидић, 2009². 
Можда су изрази субјекат-објекат лоши, јер не би однос требало делити на објект сазнања и субјект који сазнаје, будући да нас та подела ставља у рам ствари. У сваком случају, из саме методологије коју предлажем и коју предлаже Св. Максим Исповедник и иначе православно хришћанство, произлази да нема објекта. Сви ту постају личности. Међутим, кад начелно говоримо о сазнању онда условно можемо да користимо те термине. Претходно, свакако, морамо разјаснити на који начин сазнајемо. Историја гносеолошких приступа нам може бити од користи у анализи ове проблематике.

Апофатичко богословље, онакво каквим се оно јавља код Дионисија Ареопагита, али и пре њега код кападокијских отаца, тиче се суштине Божје. Наиме, оно што је у Богу апсолутно несазнајно то је божанска суштина. Бога као Личност је могуће познати. И не само да је могуће, у томе је и једини начин нашега спасења. „А ово је живот вечни, да познају тебе јединога истинитога Бога и кога си послао Исуса Христа" $\left(\mathrm{JH}_{17}, 3\right)$ каже Христос, молећи се Богу Оцу пред своје страдање. Међутим, познати Бога као Личност није могуће на основу својстава која има по природи, ма колико она узвишена била. Јер ако познајемо Бога на основу тога што је Он добар, милостив, што је љубав, свемогућ итд. онда га не познајемо као апсолутну и непоновљиву Личност. Он постаје ствар, као и свака друга ствар која може имати своја својства. Ни човека не познајемо као личност ако га познајемо на овај начин. Човек постаје за нас апсолутна личност од које зависи и наше постојање само ако га волимо. На тај начин он постаје апсолутна личност упркос његовим физичким својствима која могу бити различита. Познати Бога, дакле, као непоновљиву и за нас апсолутно потребну Личност, могуће је једино ако га љубимо ${ }^{2}$. И то само у Цркви кроз поистовећење са Господом Исусом Христом, Сином Божјим. Зато што једино Христос познаје Бога Оца, јер је Он као Син у вечној љубавној заједници са Њим. Идентитет Бога Оца управо извире из заједнице са Сином и Духом Светим. Бог је вечни Отац јер вечно има Сина. Кроз поистовећење наше са Христом у Цркви, Бог постаје и за нас Отац.

Међутим, овај израз „поистоветити се са Христом“ у Цркви не значи нити идејно, нити психолошко поистовећење са Њим, нити сазнање Бога као Оца на тим основама. Отац мога пријатеља не може онтолошки бити и мој отац, нити на основу имена којим га ја зовем (има сина кога ја познајем), нити пак на основу пијетета и поштовања према њему, ради тога што је његов син мој пријатељ. Потребно је да и ја заиста будем његов син да и Он мени био Отац. Поистоветити се са Христом у Цркви значи Духом Светим постати Тело Христово, односно члан Његовог Тела тај исти Христос, кроз причешће у Св. Евхаристији. На тај начин сазнајемо Бога као Оца који је и нама у Христу Отац. Ово сазнање се остварује једино слободном

2 Уп. Мидић, 2017. 
вољом, јер нико не постаје члан литургијске заједнице осим слободно, из љубави. Но, у чему се састоји ова слобода-љубав човека према Христу?

На основу литургијског искуства у којем Христа сусрећемо кроз човека који је икона Христа, Христа као Сина Божјега можемо познати у једном конкретном човеку и једино слободом, љубављу. Ако пожелимо да имамо заједницу са њим, у њему ћемо видети Христа упркос природи и чињеницама које могу да указују и на супротно. Уколико тражимо чињенице на основу којих ћемо познати да је у Литургији заиста присутан Христос Богочовек, остаћемо изван Цркве. Не зато што не постоје чињенице које идентификују присуство Христа кроз човека у Литургији, него зато што се на основу чињеница не може нико идентификовати ако ми не желимо да га као таквог признамо. Да бисмо признали присуство Христово у Литургији у лицу човека, односно епископа који приноси дарове као тело и крв Христову за спасење свих који се Њиме причешћују, потребно је да слободно хоћемо да га признамо. И то учешћем у Литургији, а не другачије. На овај начин имамо заиста поуздано знање о Богу, истинито знање које се заснива на слободном заједништву са Богом, а не на сакупљању информација о Богу на основу Његових својстава.

Дакле, што се тиче апофатичког богословља мислим да је рано да њега тражимо код Св. апостола Павла. То ће бити проблем који ће се појавити касније, са појавом тзв. ареопагитских списа, негде у петом веку, приписаних Дионисију Ареопагиту. Ту се ради о тзв. айобайичком бойословљу које говори о несазнативости Бога управо због Његове Природе. Ради се наиме о томе да се Он не може познати по природи јер се налази са друге стране свега створеног. Као Личност међутим, Бог се може познати. Али, пре него што пређемо на проблем богопознања код Дионисија и данас, морамо најпре да направимо један увод.

Наиме, још од Климента Александријског, а поготову код Оригена, појављује се једна нова врста сазнања, једна нова онтологија у хришћанству. Она није ठила изворно хришћанска, али је имала утицаја на хришћанске кругове, поготово на монашке. Та нова онтологија ће преко Евагрија Понтијског, у петом веку, некако доспети и до списа Дионисија Ареопагита, односно псеудо-Дионисија Ареопагита. У чему је у ствари проблем замене онтологије? Ориген и Климент Александријски су хришћанску онтологију заменили гносеологијом. Гносеологија је постала онтологија, свакако у једној различитој форми од оне коју ћемо имати у време рационализма, почевши од Августина и Боеција, преко Декарта и енциклопедиста па све до данас. Разлика између рационализма и Оригенове и Климентове, уопште александријске, поставке гносеологије је у томе што је средњовековна гносеологија кулминирала управо у Беконовој поставци да сазнање постаје прагматично, да се претвара у моћ, да се претвара у искоришћавање свега онога што сазнајемо. Код Оригена и код Климента нећемо имати тај случај, 
али ћемо имати управо знање ради знања. Но, у чему је ту проблем? Да се мало вратимо на Оригена и Климента Александријског.

Они су били под непосредним утицајем платонизма, у коме је у ствари истина овога света виђена у једном вечном свету идеја које су отеловљене у видљивом свету. Дакле видљиви свет је сачињен, створен на основу тих идеја, и уколико партиципира у идејама он има истине у себи. Под утицајем платонизма Ориген те идеје није више назвао идејама, него духовним бићима, односно лоїосима ствари. Интересантно је да и код Климента Александријског, и код Оригена који је био његов ученик, имамо хришћанске почетке учења о логосима ствари. Наиме, свака ствар има свој логос, при чему су они сви скупљени у Божанском Логосу. Међутим, Ориген ће говорити о једном вечном духовном свету у Божанском Логосу што се не слаже са хришћанским тумачењем. Говорећи још о паду који се догађа управо у тој сфери, дакле у духовној сфери, још пре постања света. Свет ће тако настати као последица тога пада, као казна Божја, тако што ће Бог створити материјални свет и у њега затворити духове, те преегзистентне душе како је то говорио Ориген.

Ослобођење, односно спасење, по Оригену, требало би у ствари да буде ослобођење од свега што је материјално. Но, интересантно је напоменути да Ориген у ствари говори о Логосу који је у грчкој философији увек имао везе са сазнањем, са логиком и са оним рационалним. И управо ту линију Оригенову која говори о спасењу као ослобађању од свега материјалног и враћању у првобитно стање, разрадиће монашки кругови, и то можда најбоље Евагрије Понтијски. Сйасење ће ту заправо бити сазнање. Повратак у првобитно стање, односно јединство са Богом, и то са Богом Логосом, по Евагрију и по Оригену, моћи ће да се оствари једино умним силама. Зато је основни моменат био очишћење ума од свега што је страсно, од свега што је материјално, да би ум, чисти ум, могао да созерцава Божанског Логоса и тако буде у заједници са Њим. Из тога је требало да произађе спасење и повратак у првобитно стање, односно у вечни живот. На овај начин имамо једну іносеолоіију која је заменила стару хришћанску онйолоіију, онтологију заједништва и литургијског богослужења, и у њему сазнања Бога.

Наиме, до Оригена и упоредо са Оригеном, постоји једна друга линија коју можемо назвати апостолском. Њу, у другој хришћанској генерацији, прати Св. Игнатије Богоносац, затим Св. Иринеј Лионски унеколико можда Јустин Мученик, премда он више нагиње овој грчкој, философској линији. (Када говори о Божанском Логосу он више има на уму стоичко него хришћанско схватање Логоса.) У чему се састојала онтологија Св. Игнатија Богоносца, уопште апостолска онтологија? Она је била везана за литургијско сабрање, односно евхаријстијско сабрање, где је у ствари

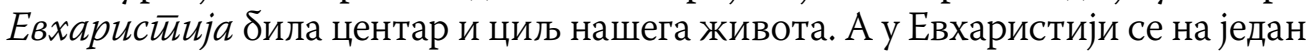


видљиви начин, преко дарова које приносимо, ми причешћујемо, али сада не Божанским Логосом очишћеним од материје и од свега материјалног, него Божанским Логосом који се оваплотио, узео тело и крв. Интересантно је да Ориген говори против овакве једне концепције. Он хришћане који долазе на Литургију и причешћују се назива хришћанима нижега ранга. Виши ранг чине они хришћани који чистим умом сазнају Божанскога Логоса. Ово је утолико интересантно за нашу тему што ће се одавде развити тема апофатичког богословља, које ће Запад покушати да протумачи управо на овај оригеновски и евагријевски начин. А то значи кроз мистицизам изаћи из материјалне стварности и тако сусрести Бога!

Ако Дионисија упоредимо са Евагријем и са Оригеном, тада Дионисије иде по тој линији. Када он говори о сазнању Бога кроз тзв. незнане, он у ствари жели да покаже да се ми, ослободивши се свега материјалног, из чега иначе по искуству добијамо неко сазнање, апсолутно ослобађамо тзв. позитивног сазнања и појмова којима би евентуално могли да идентификујемо Бога. Дакле, ослобођењем од материјалног прелазимо са оне стране ово-

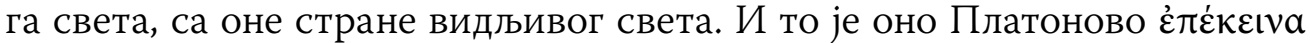
$\tau \tilde{\eta} \varsigma$ oủoíaৎ које ће користити и списи Дионисија Ареопагита. Дионисије ће често употребљавати и префикс ن́лย́ остављајући и материју и све оне појмове које нам материјални свет даје у сазнању и тражећи Бога у једном Божанскоме Примраку, управо онако како га је и Лоски протумачио. У једном, да тако кажем, Божанском Незнању. Када пређемо ову стварност и изађемо у неку другу стварност, тада излазимо из позитивног знања те то више не би могло да се назове знање, него незнање управо у односу на ову стварност. Из овога ће се на Западу пројавити мистицизам, наиме, будући да су западни теолози, као што је рецимо Дунс Скот, овако протумачили Дионисијеве списе, управо на Западу ће цветати мистицизам.

Међутим, постоји један велики Св. Отац који ће на сасвим другачији начин протумачити списе Дионисија Ареопагита, и који ће спасити гносеологију, ослободити је од оних онтолошких примеса платонизма и ослонити је на литургијску онтологију. Тај свети отац је Максим Исповедник. Шта је карактеристично за Св. Максима Исповедника, односно за његово тумачење Ареопагита? Као што смо већ нагласили Дионисијево апсолутно непознање Бога тиче се Божанске природе. Бога по природи нико не познаје осим Њега самог. Међутим, Бог се може познати, као што показује и сам Дионисије, по својим енергијама, тј. као Личност, како ће то касније Св. Максим говорити управо тумачећи Дионисијеве списе. Ово је могуће тим пре што се Син Божји као личност оваплотио поставши човек. Но то богопознање подразумева личну заједницу са Христом у Литургији где се Христос, кроз сусрет са човеком, сусреће као жива личност а не као идеја. На жалост, данас наше познање Бога, и не само Бога него и свега што нас 
окружује, заснива се на иgејама о њима. Зато се данас светом управља из канцеларије и преко медија, од којих је најсврсисходнија телевизија, јер људи немају однос са Живим Богом и људима, као ни са стварима, него само са њиховим идејама.

Но да се вратимо Св. Максиму. У чему се састоји максимовски приступ проблему богопознања? Одмах треба нагласити да се Св. Максим враћа апостолским коренима. На основу тога он је против Оригена и на основу тога он превазилази оригенизам. Он ће као циљ спасења поставити јединство са овайлоћеним Христом, дакле Христом који је ушао у свет и узео тело и постао човек. Ту је темељна разлика између Св. Максима са једне, и Оригена и Евагрија Понтијског са друге стране. Дакле не више сједињење са Логосом Божанским, који подразумева одстрањење свега што је материјално и гносеологију која ће извирати из чистога ума, очишћенога ума и из превазилажења свега искуственог што долази до нас, него се у жижу ставља литиуріијско сабрање. Јер ако је оваплоћени Христос циљ свега, а Св. Максим ће не једном рећи да је због оваплоћења све што је створено створено, да је то и циљ и замисао Божја и почетак и крај,

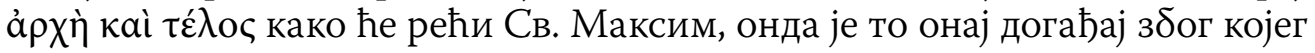
је створен свет. Будући да је оваплоћени Логос, оваплоћени Син Божји тај са којим треба да се сјединимо, Он сам указује пре свега на јединство са другим човеком, али на јединство у литургијском сабрању. У Литургији, кроз јединство са сабранима у Христу, остварујемо најприснију заједницу са Њим.

Подвижнички карактер, који је код Оригена био једна битна претпоставка за очишћење ума, Св. Максим неће видети у борби против материје и у ослобођењу од материје, него у ириношењь свей $а$ Богу, у уношењу света у литургијску заједницу. Управо у томе ће бити суштина подвижничког живота за Св. Максима. Дакле, изборити се не да будемо везани за ствари тиме што ћемо у стварима видети спасење, него тиме што ћемо ми спашавати ствари и свет око сеઈе, и то уносећи га у литургијску заједницу, где ће он да постане, како је то Св. Максим говорио, космичка Литургија, где ће да постане Тело и Крв Христова, и кроз кога ћемо и ми, партиципирајући у њему, имати заједницу са Богом, оваплоћеним Богом који се пројављује у литургијском сабрању.

Дакле, знање ће за Св. Максима Исповедника бити везано за подвижнички живот, али ће пуно сазнање Бога као Личности бити искуствено, литургијско сазнање. Зато ће Св. Максим Исповедник говорити да само оно што се воли може да се сазна. Ово стога јер је љубав за њега један

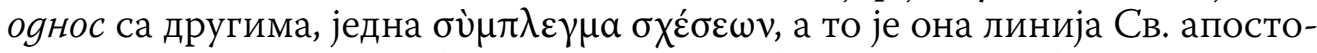
ла Павла. За њега је љубав литургијско сабрање. То је љубав Св. апостола Павла према Богу. Ако неко пажљиво чита Посланицу Коринћанима видеће да Св. апостол Павле говори о литургијском сабрању као Цркви, 
и одмах затим говори о љубави. Дакле, ако се чита у континуитету 12. и 13. глава Посланице, а Св. апостол Павле није Посланицу делио на главе и на стихове, то смо ми касније поделили, може се добити та јединствена целина која нам говори да апостол Павле не замишља љубав као психолошку категорију, како ће љубав касније протумачити Августин, него као један однос, један литиуріијски оgнос. Ако ово имамо у виду разумећемо зашто су се Литургије у старо време називале вечере љубави.

Дакле, код Св. Максима имамо један сасвим другачији приступ Дионисију Ареопагиту. Интересантно је да ће управо Св. Максим почети да говори о логосима ствари. Он наиме узима тематику из списа Св. Дионисија Ареопагита, али ће први протумачити логосе ствари другачије него што смо то имали код Климента, Оригена и Евагрија. У чему је суштина Максимовог учења о логосима? Св. Максим Исповедник ће логосе ствари први пут поистоветити са вољом Божјом. Дакле не више са умом Божјим, него са вољом Божјом. Зашто је ово важно и толико револуционарно у развоју хришћанске теологије?

Бавећи се проблемом како и на који начин Бог познаје свет, да ли умно и на основу природе света, као што су стари Јелини тврдили, Св. Максим одговара: Бог не познаје свет нити умно нити на основу његове природе, него својом вољом и на основу своје воље, јер га је слободном вољом и то ни из чега створио. То значи да Бог не сазнаје свет нити на основу идеје о свету или пак анализирајући његова природна својства, нити се Његово сазнање о свету састоји у томе што Он може проникнути у најмању честицу света и знати њену структуру. Бог идентификује свет вољом својом и мимо његове природе, чинећи га на тај начин истовремено да постоји и да јесте то што јесте. Познати некога на основу своје воље, слободно, зато што желите да га познате, подразумева да га идентификујете као постојећег упркос његовој природи, чак и мимо његовог физичког присуства. А то значи да му дајете идентитет и постојање истовремено. (Јер идентитет и постојање некога, тј. да га познајете и да као такав постоји за вас, могуће је само ако га ви слободно, својом вољом признате. Иначе, ако га не желите, ви га и не познајете, и он може постојати, али не постоји за вас. Ово друго се нама догађа зато што ми не можемо другоме, кога не желимо, да ускратимо постојање јер ми нисмо Бог, нити смо га ми створили. Створио га је неко други мимо наше воље и зато он може постојати и мимо наше воље. Ми га не познајемо, јер га не желимо и на тај начин он за нас не постоји, иако по природи постоји. Међутим, Бог је својом вољом све створио из небића у биће и у Богу се вољна идентификација некога поистовећује са његовим постојањем. Оно што Бог жели то и постоји, и то Бог познаје. Иначе, ако то не признамо онда је постојање света независно од воље Божје, што значи да Бог престаје да буде апсолутни Творац свега, престаје да буде Бог. На овај начин, тј. слободно сазнати неког, а то 
значи и створити неког из небића, може једино Бог који је Личност. Бог апсолутно познаје свет јер је он једино апсолутно слободан, па и у односу на свет, тј. једино је Бог апсолутно Личност ${ }^{3}$.

Са друге стране, и свет кога Бог као Личност, као слободно биће, ствара и познаје јавља се у односу на Бога као Личност. Бог га познаје као Личност, а то значи да и постоји у личности, и то као Христос, и у личности Христовој постоји све што је створено, на шта указује и апостол Павле говорећи да је свет створен кроз Христа, за Христа и у Христу. И не може бити другачије кад Бог својом слободом, својом љубављу ствара свет, тј. слободом га познаје. Свет би био једна безлична природа у случају да постоји мимо воље Божје, било сам по себи или као датост, као створен од неког другог. У том случају би Божје знање о свету и само постојање света биле две различите стварности. Свет би могао да постоји и ако то Бог не жели, и ако би, да се тако изразимо, Бог игнорисао свет рекавши му: и ако постојиш, за мене не постојиш! Као што то ми људи кажемо некоме кога не желимо. А то је апсолутно немогуће. Зато Св. Максим наглашава да је Бог створио свет у оном тренутку кад је то зажелео. Чак подвлачи и то да Бог познаје свет и пре него да га створи, и пре него да свет постоји, желећи да нагласи да Бог познаје свет не на основу природе света, него да га познаје као своју вољу, тј. љубављу, што ће рећи да га ствара љубављу.

Овде се знање поистовећује са постојањем зато што и једно и друго извире из воље Божје. Знање Божје о свету нити претходи постојању света, нити пак постојање света претходи знању. Јер шта је то што Бог познаје а оно не постоји, или опет може ли се шта појавити а да га Бог не познаје! Другим речима, знање Божје о свету као и постојање света поистовећују се са љубављу Божјом према свету. А та љубав Божја према свету је Син Божји Исус Христос, по речима апостола Јована: „У томе се показа љубав Божја према нама што је Бог Сина свога Јединороднога послао у свет да живимо Њиме“. Зато наше поистовећење са Христом кроз учешће у Св. Литургији подразумева Божје познање нас, и не само познање, него као што смо већ рекли, и постојање. Зато ће апостол Павле у Посланици Коринћанима нагласити: да онај који љуби Бога познат је од Бога, и да он познаје Бога. Јер, учешћем у Литургији ми истински познајемо Бога као свог Оца, јер се у Литургији поистовећујемо са Христом, оваплоћеним Сином Божјим који једини познаје Бога.

У супротном, ако логосе Божје поистоветимо са умом и са тим такозваним умним, рационалним продуктима, тада нужно долазимо до оригенизма и видимо да свет заиста нужно постоји, да је он у неку руку еманација Бога, да Бог, имајући ум, од вечности мисли, а самим тим од вечности созерцава и види тај свет, који пре своје материјалне форме препостоји као мислена форма, као скуп логоса у Божанском Логосу, Божанском Уму који

3 Уп. Зизијулас, 2016. 
је овде назван Сином Божјим. Св. Максим Исповедник, поистовећујући логосе Божје са вољом Божјом, чини прелаз са терена нужносии и на терен слобоge. И сада, за Св. Максима све ствари које су створене имају свој логос у Христу. То значи да их Бог жели и познаје у Христу, јер Бог је хотећи, њих створио у Христу и за Христа.

Треба овде напоменути још једну ствар која ће нам потврдити да Св. Максим Исповедник Дионисија Ареопагита хоће да протумачи у контексту хришћанске онтологије а не Оригенове и уопште старогрчке, платоновске и новоплатоновске онтологије. Потврда томе је схватање истине по Св. Максиму, изречено управо у схолијама Св. Максима на Дионисија Ареопагита. Каква је то дефиниција? Св. Максим дословно каже на грчком: $\dot{\eta} \pi \alpha \lambda \alpha \iota \grave{\alpha}$

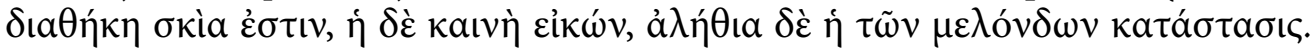
Преведено на српски то би значило: Стари завет, дакле оно што је било на почетку, је сенка, Нови завет је икона, а истина овога света то је будући век и стање у будућем веку. Ово је нешто заиста радикално ново не само у односу на класичну философију, него и у односу на оригенизам против кога се Св. Максим овде бори. Ориген ће истину сместити у прошлост, у йочейак. Откривање истине за Оригена ће бити враћање у прошлост, враћање на почетак. Насупрот томе Св. Максим ће увек говорити да је

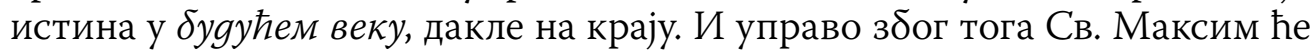
имати лийуріијску концепцију сазнања и уопште истине.

Да ово мало појаснимо. Ако је истина овога света у првобитном стању, дакле у нечему што је било у прошлости, тада нам ништа друго не остаје него да се ослободимо свега овога што имамо, свега материјалног, и да тежимо да се вратимо у то првобитно стање. У том случају су и време и материја непријатељи истине, управо онако како је било и код Платона. Треба се ослободити и времена и простора да бисмо уопште дошли до истине. Међутим, у концепцији Св. Максима, будући да је истина у будућем веку, онда се и време и простор афирмишу и они се у ствари спасавају. Наше спасење почиње caga u овge.

Са друге стране док је подвижништво у оригеновској концепцији, у којој је истина везана за прошлост, повратак у првобитно стање, ослобођење од материје (што су иначе монашки кругови који су били под утицајем Оригена и подвлачили), у максимовској концепцији подвижништво је управо спасење читаве природе, спасење света и свега што је материјално, да би тај свет могли да уведемо у јединство са Богом, у јединство са Христом, сада и овде у литургијској заједници која је икона будућега века.

Постоји још једна напомена коју сматрам врло важном, а која се заборавља у нашој теологији, и није баш присутна код наших теолога. Ради се наиме о чињеници да Св. Максим говори о тзв. иконијској йеолоїији. То значи да овај свет има истине у себи али је та истина иконична. Ова истина је само икона истине која ће доћи у будућем веку. И зато ће Св. 
Максим Исповедник, када тумачи Дионисија Ареопагита и његов спис „О небеској јерархији“ говорити о јерархији овде, о литургијској јерархији као о икони ठудућега века. Нажалост, они који су тумачили Ареопагита ठез посредништва Св. Максима видели су и литургијску јерархију и читав овај поредак овде у оригеновском смислу, у смислу да је све ово овде само одсјај онога вечнога света, оног духовног света који у ствари сапостоји паралелно са овим. Отуда, под утицајем оваквих тумачења, читав је подвижнички живот добио једну димензију по којој у њему смрт постаје ослобођење, будући да се смрћу пресељавамо из овога лажнога живота у онај горњи истинити. Све материјално је изгубило важност, постало је не само неважно, него је постало непријатељско. То није изворно хришћанска мисао, јер изворно хришћанска мисао не би никад могла да се сложи са тим а да истовремено говори о оваплоћењу Логоса. Наиме, оваплоћењем Бога Логоса материја добија нешто најузвишеније улази у заједницу са Богом. Дакле Бог је дошао да спаси материју а не да се ослободи од ње. На крају крајева, ако и ми желимо да будемо иконе Христове, треба и ми да спасавамо материју а не да се боримо против ње.

Дакле да се вратимо апофатичкој теологији. Апофатичка теологија, виђена кроз призму Св. Максима, је теологија која се не оснива на оној платоновској концепцији сазнања у којој ћемо се сазнавајући сећати прошлости, а то код Платона значи потискивати заборав и долазити до истине. Са друге стране, Св. Максим Исповедник такође говори о сазнању, али не

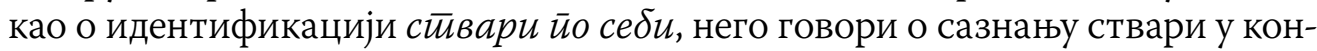
тексту њиховог йpegogpeђењ $a$, у контексту онога за шта их је Бог створио, у контексту њихових логосности. То значи да ћемо сваку ствар сазнати у зајеgници са Христиом, те ако је погледамо из визуре заједнице са Христом знаћемо њен прави идентитет. То је право апофатичко богословље кога заступа Св. Максим Исповедник. Свети Максим сазнаје ствари у односу на будући век, а не као Ориген који их сазнаје у односу на прошлост. У том контексту сазнаје се и Бог. За Св. Максима сазнайи Бога значи љуубитии Бога. И овде сада долазимо до једне новине коју није имао ни Ориген, али коју није имао ни Дионисије Ареопагит, а то је управо оно, код Св. апостола Павла, да љубављу некога сазнајете, а то сазнање тад пред вама онога кога сазнајете пројављује као непоновљиву личност. Наиме, када некога волите тада у њему видите део сеઈе, односно извор свога живота. И тада се тај gруіи пројављује вама као апсолутно и непоновљиво биће које се не може упоредити ни са чим, нити се може заменити нечим. Тада је тај

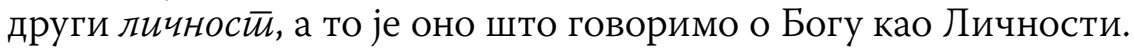

Све ово Св. Максим црпе из теологије кападокијских отаца која је имала икону у литургијском сабрању. Бог је апсолутна и непоновљива Личност јер је зајеgница личностиц, и то љубавна заједница личности. Отац јесте Отац зато што има заједницу са Сином и Духом Светим. И нико, каже се 
у Светом писму, не познаје Оца до Син, и коме Син хоће открити. То ће рећи, да љубављу својом и односом својим који има Син према Оцу, Он га признаје и идентификује као апсолутну и непоновљиву личност, као Оца. И ми Бога можемо сазнати само преко Христа, али преко Христа овайлоћеної. Иначе, сваки други пут нас води до идентификације Бога не као Личности, него до идентификације Бога као идеје, што смо имали код Климента Александријског, и, рекосмо, код Оригена.

Што се тиче савремене философије, па и савремене теологије коју у великој мери одређују савремени философски токови, она се може у једној речи окарактерисати као једна комбинација рационализма и инgивиgуализма ${ }^{4}$. Рационализам, односно његов прерани развој, натерао је Ничеа да, гледајући на тај развој, донесе закључак да је Бог мртав. Но, да Ниче живи у ова наша времена, или можда са генерацијом која ће доћи после нас, он би редиговао своје мишљење али не битно. Он би рекао не само да је Бог мртав, него и да је човек мртав, те да смо сви мртви и да је готово више. Ово стога јер је консеквенца смрти Бога смрт човека и смрт свих нас, што ће се и догодити, и у физичком смислу, само ако ова наша цивилизација настави да се развија овим темпом и на овим основама.

О чему се ту заправо ради? Наиме, још је Августин као прекретница, да тако кажем, измећу Источнога и Западнога хришћанства, поставио једно сасвим другачије тумачење Бога, па самим тим и једну другачију хришћанску онтологију. Он је Бога видео као јединку, као Јединицу. Не дакле као Једнога који је заједница личности, него као Једно. И у тој Јединки он је хтео да нађе места за тројичну форму, али на тај начин што је, типично, видео да и човек по себи и као јединка има неку тројичну форму, наиме ум, вољу и осећања. На основу тога он је хтео да протумачи и Тројичнога Бога. Не дакле као заједницу личности, него као јединку која унутар себе има неке разлике, неку тројичност. И зато је карактеристична и терминологија коју је употребио у списима De civitate Dei и De Trinitate. Он је Бога поистоветио са вечним Умом који има Логос, а то значи знање, и има љубав. Да би постојао тај вечни Ум, он мора да има знање, јер који је то ум који нема знање? Будући да је Августин поистоветио Логос, дакле Сина Божјега, са знағем што значи да се знање увек рађа из Ума, он је, на основу тога, протумачио да се Син рађа од Оца, као и то да Отац себе сазнаје кроз Логос, дакле кроз самосазнање. Духу Светом је нашао улогу, да тако кажем, везивне компоненте између Оца и Сина, и Он је ту, како каже Августин, nexus amoris. Будући дакле да Бог Отац себе сазнаје само кроз свој Логос, сазнајући себе Он љуби себе. Дакле Бог јесте и љубав.

Интересантно је да је још Лоски напоменуо да Filioque извире из авгу-

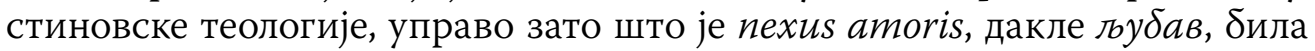
зависна од знана. Онда када Бог сазнаје самога себе онда и порађа љубав.

4 Мидич, 2013. 
Отуда Августин тврди да само оно што сазнамо то и волимо. Не може се ништа волети пре него га сазнамо. Дакле, управо је зато Дух Свети у римокатоличкој теологији био завистан од Сина. Зато што је Син поистовећен са знањем. Одатле и читава теологија о Filioque, но да се сад тиме не бавимо.

Оно што је за нас важно је то да је оваква теологија породила једну нову онтологију, а то је онтологија индивидуализма. Интересантно је да Августин човека види као јединку, при чему идентитет човека зависи од његовог самосазнања. Самосазнање се састоји у томе што будући да човек има ум, а ум му је дат да идентификује себе, он идентификује себе тако што сазнаје себе. Из такве поставке није могло а да не следи оно што ће Августин говорити, а то је заправо такозвана психоанализа. И ово што ми, нажалост, и код нас имамо као исповест, дакле једно логичко, рационално претурање по просторијама душе, изношење тога напоље и класификација тога у смислу шта је грешно а шта је добро, није уопште православно. Ми дакле исповедамо наше мисли али мисли које су биле везане за наше такозвано унутарње биће. Изврћемо себе напоље!

Августин је утемељио индивидуализам који постаје синоним за постојање, при чему то постојање констатује ум, ratio. Одмах после Августина доћи ће Боеције и читава плејада философа, доћи ће Декарт, и будући да је у тој традицији ум тај који самом човеку одређује идентитет, Декарт је извео закључак да ум одређује и постојање. Зато ће Декарт и рећи cogito, ergo sum - мислим, дакле постојим. Дакле, када могу да размишљам о самом себи, то значи констатујем да јесам. На тој основи ће се развити рационализам и једно увежбавање ума да би он могао правилно да дође до закључка шта јесте а шта није, односно да он постане мерило самога постојања и истине. Тако ће Запад утемељити рационализам.

Француски енциклопедисти ће на том трагу развити такав школски систем који ће имати за крајњи циљ оспособљавање ума за то да он постане врховни судија у погледу одређивања тога шта јесте а шта није, шта је добро а шта зло. И нормално, ум коме тај и такав школски систем додели

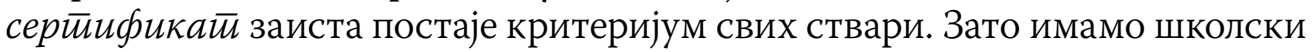
систем који издаје дипломе, те сви људи који су добили диплому одлучују о свету и мисле да су позвани да доносе суд о томе шта јесте а шта није.

Ако сад у овом контексту сагледамо теологију, што је за нас посебно битно, онда кроз ову схоластику, кроз рационализам, добијамо један по-

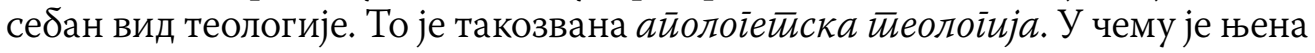
суштина? Па управо у томе што ако је ум тај који мери истину, односно одређује шта је истина а шта не, онда будући да теологија барата са нечим што се не може увек рационалним средствима потврдити, и будући да све оно што ум тим истим средствима не верификује постаје сумњиво, и у теологији је све оно што ум не потврди постало сумњиво. И не само да 
је постало сумњиво, него је проглашено за непостојеће. Теологија је онда прибегла једној посебној врсти реакције. Наиме, управо уважавајући наметнути јој метод, користећи исти метод, она сад покушава да покаже да теологија има права да постоји и да Бог постоји. Из тих покушаја рођена је и „Summa theologiae“ Томе Аквинског који ће логичким разлозима покушати да покаже да постоји Бог, и не само да постоји Бог него и да оправда постојање Цркве, постојање хришћана уопште. Наравно, све ће то касније постати потпуно неупотребљиво, јер, као што смо видели код Бекона, свако знање које не може да се употреби, које не може да се искористи, постаје равно незнању. Без обзира на то што је оно можда логички заокружено, ако не може да се употреби оно је равно незнању. Савремена теологија ће онда, нажалост, покушавати да изнађе нове аргументе за то да је она и те како корисна, да су теолози корисни савременом свету. Тако римокатоличка и протестантска теологија, у последње време, покушава да покаже да је Црква потребна, пребацујући тежиште на хуманитарни план, показујући да, ето, ако не буде теологије која се бави хуманитарним делатностима онда неће бити никога да се стара о сиромасима итд. Све ово, нажалост, оставља последице и на нашу православну теологију.

Гносеологија је врло комплексна тема и немогуће ју је сместити у оквире једнога чланка. Али наш циљ је да барем начнемо ове проблеме и покажемо да савремено тумачење апофатичке теологије има блиске везе са савременим начином сазнања и оним што је нас оптеретило, а то је рационализам. Мислили смо тако да су Св. Оци говорили о једној другачијој врсти сазнања, таквој у којој се иде на чисте појмове, са оне стране свега искуственог и рационалног. То би требало преиспитати, а поготову књигу покојног Владимира Лоског О мистиччној йеолоіији Исйочне Цркве у којој он говори о мистицизму оригеновског типа а не, да тако кажем, аутентично максимовског или православног типа. Отац Георгије Флоровски је с правом рекао да је књига опасна за читање. Православна мистика и православни начин богопознања је нешто сасвим друго. Књига Лоског свакако има своје позитивне стране, али је треба читати са једном дозом опреза и увек имајући на уму Св. Максима. Св. Максим је заиста један генијалан ум који је био прекретница у једном периоду историје Цркве када се одлучивало да ли ће теологија отићи у неоплатонизам или ће задржати апостолске корене. Ово друго је захваљујући Св. Максиму преовладало, и имајући у виду теологију Св. Максима Црква је осудила и оригенизам и Евагрија Понтијског и све оно што није припадало хришћанској традицији. 


\section{Литература}

Зизијулас, J. (2016). Света Тројица и људска личност. Саборносй, 10, 9-16. Мидић, И. $\left(2009^{2}\right)$. Од Бога као више силе до Бога као личности. У И. Мидић,

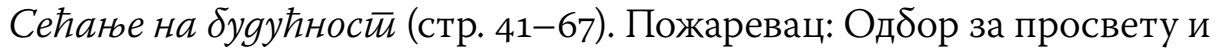
културу Епархије ठраничевске.

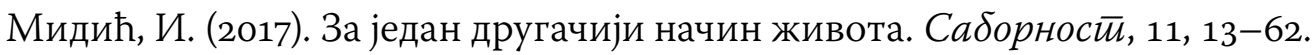

Мидич, И. (2013). Православное богословие сегодня. Проблемы и пер-

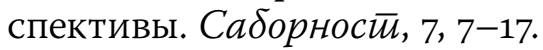




\section{Ignatije Midić}

University of Belgrade, Faculty of Orthodox Theology, Belgrade

\section{The basic elements of the Orthodox gnoseology}

The fact is that our modern knowledge, transmitted to power, transmit-

1 ted into technology, threatens not only us as humans, but also the entire planet and the entire system of life. That's why the problem of knowledge (also knowledge of God) is very current. The Orthodox contribution to the gnoseological question is reflected in the approach that the knowledge is considered as personal, ecclesiastical and sotiriological category, it's evidenced by both traditional and sacramental sources.

Key words: gnoseology, reason, knowledge, love, Church, personality.

Датум пријема чланка: 10. 3. 2018.

Датум прихватања чланка за објављивање: 8. 10. 2018. 